\title{
PCR-positivity in harvested bone marrow predicts relapse after transplantation with autologous purged bone marrow in children in second remission of precursor B-cell acute leukaemia
}

\author{
Susan F. Vervoordeldonk, ${ }^{1}$ Pauline A. Merle, ${ }^{1}$ Henk Behrendt, ${ }^{2}$ Eric J. Steenbergen, ${ }^{1}$ Henk van den Berg, ${ }^{2}$ \\ Elisabeth R. van Wering, ${ }^{3}$ Albert E. G. Kr. von dem Borne, ${ }^{4}$ C. Ellen van der Schoot, ${ }^{1,4}$ Eleonore F. van \\ Leeuwen $^{2}$ and Ineke C. M. Staper-Cortenbach ${ }^{1}{ }^{1}$ Central Laboratory of the Netherlands Red Cross Blood Transfusion \\ Service and Laboratory for Experimental and Clinical Immunology, University of Amsterdam, Amsterdam; \\ ${ }^{2}$ Childrens Hospital 'Emma Kinderziekenhuis/Kinder AMC', Amsterdam; ${ }^{3}$ Dutch Childhood Leukaemia Study Group, \\ The Hague; ${ }^{4}$ Department of Haematology, Academic Medical Centre, Amsterdam, The Netherlands
}

Received 13 May 1996; accepted for publication 4 October 1996

\begin{abstract}
Summary. Purging of autologous bone marrow (BM) grafts of children in second remission after a relapse of precursor B acute lymphoblastic leukaemia (ALL) in the BM has been carried out in our laboratory since 1987, initially by complement mediated cell lysis. This protocol was extended by performing an immunorosette depletion before lysis with complement. The aim of the present study was to assess by polymerase chain reaction the presence of residual leukaemic cells in the BM grafts before and after purging. The results were then correlated to clinical outcome. In 24/ 28 patients a PCR product was obtained by amplification of $\mathrm{IgH}$ and/or TcR junctional regions. BM before purging was available for analysis in 13 patients. We found that leukaemic cells could be detected in $8 / 13(62 \%)$ of these grafts before purging . All these eight patients experienced a
\end{abstract}

relapse, regardless of whether the purging procedure had been successful (defined as achievement of PCR-negativity) or not. In contrast, none of the five patients with PCRnegative grafts before purging relapsed $(P=0.0008)$. One patient died due to transplant-related toxicity. Of the remaining 23 patients, nine patients received a PCR-positive $\mathrm{BM}$ graft after purging. All these nine patients experienced a relapse as compared to 6/14 whose BM was PCR-negative after purging $(P=0.0072)$. Two of eight PCR-positive BM grafts could be purged to PCR-negativity. Thus, improvements both in treatment of leukaemia and in purging efficacy are still needed.

Keywords: purging, acute lymphoblastic leukaemia, autologous bone marrow transplantation, polymerase chain reaction.
In approximately $70 \%$ of children with precursor B acute lymphoblastic leukaemia (ALL) long-term complete remission can be achieved with current chemotherapy (Pui, 1995). However, children experiencing a relapse in the bone marrow (BM) have a poor prognosis. Different chemotherapeutic regimens have resulted in a 5-year leukaemia-free survival of $20-30 \%$ in this group of patients (Behrendt et al, 1990; Henze et al, 1991; Culbert et al, 1991). Following high-dose chemotherapy combined with transplantation of allogeneic or autologous BM, leukaemia-free survival has

Correspondence: Dr Susan F. Vervoordeldonk, Department of Transplantation Immunology, CLB, P.O. Box 9190, 1006 AD Amsterdam, The Netherlands. been achieved in $20-60 \%$ of cases, depending on the treatment protocol and the duration of first complete remission (Kersey et al, 1987; Sallan et al, 1989; Simonsson et al, 1989; Billett et al, 1993; Moussalem et al, 1995).

Since 1987, our laboratory has been involved in purging autologous BM grafts of children in second remission after a BM relapse of precursor B ALL. Initially, purging was performed by complement mediated cell lysis with CD9 and $\mathrm{CD} 10 \mathrm{MoAb}$ and baby rabbit complement. The purging protocol was then extended by introducing an immunorosette depletion with CD19 and CD22 MoAbs before complement lysis (Slaper-Cortenbach et al, 1990). For evaluation of the efficacy of purging, different assays for the detection of minimal residual disease in BM are used (Negrin, 1992). 


\section{Susan F. Vervoordeldonk et al}

To date, PCR is the most sensitive technique to study involvement of BM and the effectiveness of purging. Amplification of antigen receptor gene rearrangements by PCR has been extensively applied for detecting small numbers of malignant cells in ALL in both retrospective and prospective studies, as reviewed recently (Campana \& Pui, 1995). No consistent relationship between PCR results and clinical outcome was found in these reports. In some studies a single PCR-positive sample indicated an impending relapse, whereas in other studies no such relation was observed. In the present study, PCR analysis for the presence of residual leukaemic cells in autologous grafts of 28 patients with precursor B ALL both before and after the purging procedure was correlated with clinical outcome.

\section{PATIENTS, MATERIALS AND METHODS}

Cells. B-lineage ALL cell lines Nalm-6 and Nalm-16 were used, as well as the Burkitt's lymphoma cell lines Daudi and Ros-17 (gift of Professor Dr J. J. M. van Dongen, Rotterdam, The Netherlands). Cell line cells were cultured in RPMI-1640 medium (Gibco, Paisley, Scotland) supplemented with 10\% (vol/vol) fetal calf serum (FCS; Bodinco, Alkmaar, The Netherlands). Only exponentially growing cells were used in the experiments. Mononuclear cells were isolated from normal human BM by density gradient centrifugation (Ficoll-Isopaque, Pharmacia, Uppsala, Sweden; $d=1 \cdot 077$ $\mathrm{g} / \mathrm{cm}^{3}$ ). Remission BM was imitated by mixing $5 \%$ cell line cells with normal BM cells at a concentration of $20 \times 10^{6} \mathrm{cells} / \mathrm{ml}$.

Monoclonal antibodies. Four B-cell MoAbs were employed during the purging procedure: CLB-thrombo/8 (CD9, IgG2a), CLB-cALLA/1 (CD10, IgG2a), CLB-B4 (CD19, IgG1) and CLB-B-ly/1 (CD22, IgG1). For formation of tetramolecular complexes (Lansdorp et al, 1986), rat anti-mouse IgG1 (CLBRaMIgG1) and anti-glycophorin A (CLB-ery/1, IgG1) were also used. All MoAbs were produced in the Central Laboratory of the Netherlands Red Cross Blood Transfusion Service (CLB, Amsterdam, The Netherlands) and were tested for sterility, pyrogenicity and contamination with mycoplasmata and viruses.

Clonogenic assay. The purging efficacy in model experiments, in which leukaemia contaminated remission BM was imitated by mixing cell line cells with normal BM, was determined in a limiting dilution assay as described (Bast et al, 1985).

Patients. Characteristics of the 28 children with a relapse of precursor B ALL in the BM are given in Table I. After primary diagnosis, induction, central nervous system (CNS) prophylaxis and maintenance therapy was given according to protocols from the Dutch Childhood Leukaemia Study Group (DCLSG ALL-V, ALL-VI, ALL-VII and ALL-VIII) which have been described previously (Van der Does-Van den Berg et al, 1989; Veerman et al, 1990; Reiter et al, 1995; van den Berg et al, 1995). After a first relapse, patients 1-13 were treated according to local protocol. After reinduction therapy and achievement of a second complete remission, intensive chemotherapy was given for 5 months followed by ABMT. BM was harvested approximately 1 month before ABMT. Conditioning therapy consisted of busulphan and cyclophosphamide. The other patients were treated according to the DCLSG-ALL-Relapse-90 protocol. This regimen is based on the relapse protocol of the German BFM group (Henze et al, 1991). It includes high-dose chemotherapy for 5 months after attaining a second clinical remission followed by ABMT. In this group of patients the conditioning regimen before ABMT consisted of high-dose chemotherapy and total body irradiation.

Bone marrow processing and purging. BM was aspirated from the posterior iliac crests under general anaesthesia and collected into sterile bottles containing $20 \mathrm{ml}$ of a Hepesbuffered Hanks' Balanced Salt Solution (HBSS) with 4000 U thromboliquine (Heparinum natricum, Organon Technika). The BM was pooled and a buffy coat was prepared. For patients 1-10, mononuclear cells were separated on FicollIsopaque using an IBM-2991 blood cell processor centrifuge. The BM cells were washed twice and resuspended in RPMI1640 medium supplemented with 10\% PPF (purified protein fraction, CLB) and $3 \cdot 8 \%$ tri-sodium citrate (TSC). Purging was done at a cell concentration of $20 \times 10^{6}$ to $25 \times 10^{6}$ mononuclear cells $/ \mathrm{ml}$. The cells were first incubated with CD9 and CD10 MoAbs at optimal concentrations at room temperature for $10 \mathrm{~min}$. Then baby rabbit complement was added at a final concentration of $25 \%$ ( vol $/ \mathrm{vol})$. The complement was obtained under sterile conditions from 6-week-old baby rabbits that were bred under specific pathogen-free conditions. The animals were bled and the rabbit serum was isolated and tested for viral and bacterial contamination. The cells were then incubated for another $60 \mathrm{~min}$ at room temperature, with shaking of the bag for optimal lysis. Then, the cells were washed twice to remove excess MoAbs, complement and cell debris. After the purging procedure, the BM cells were cryopreserved in Hepes-buffered HBBS, $3 \cdot 8 \%$ TSC, $10 \%$ human serum albumin and $10 \%$ dimethyl sulphoxide (DMSO). For patients 11-28 a two-step purging procedure was used which consisted of an immunorosette depletion technique followed by one cycle of complement lysis (Slaper-Cortenbach et al, 1990). Patient erythrocytes were coated with tetramolecular complexes directed against glycophorin A on the erythrocyte and CD19 or CD22 on B cells. Before density gradient centrifugation, coated erythrocytes were added to buffy coat cells in a ratio of 10:1 target cells and immunorosettes were allowed to form for $15 \mathrm{~min}$. Then a ficoll density separation was performed to isolate the immunorosette-depleted light-density cells. After washing the cells, complement mediated cell lysis was performed as described above.

Collection of patient material. Mononuclear cells (MNC) obtained at relapse and/or diagnosis were isolated from BM or peripheral blood $(\mathrm{PB})$ and cryopreserved for sequence analysis. BM before purging was available for analysis in 13 patients. MNC were isolated both from $\mathrm{PB}$ obtained $1 \mathrm{~d}$ before $\mathrm{BM}$ harvest and from the harvested BM in a further 10 patients. Furthermore, approximately $10 \times 10^{6}$ cells were stored after the immunorosette depletion procedure and also after completion of the purging procedure, to assess the relative contribution of the two different purging techniques. Cells were cryopreserved in RPMI medium supplemented with $20 \%$ FCS and 10\% DMSO. After thawing the stored 
Table I. Patient characteristics.

\begin{tabular}{|c|c|c|c|c|}
\hline Patient & Age/sex & $\begin{array}{l}\text { Time from } \\
\text { diagnosis to first } \\
\text { relapse (months) }\end{array}$ & Rearrangement* & $\begin{array}{l}\text { Sensitivity } \\
\text { of patient } \\
\text { specific probe }\end{array}$ \\
\hline 1 & $5 / \mathrm{M}$ & 31 & TcR & $10^{-5}$ \\
\hline 2 & $2 / \mathrm{M}$ & 27 & TcR & $10^{-4}$ \\
\hline 3 & $2 / \mathrm{M}$ & 37 & TcR & $10^{-4}$ \\
\hline 4 & $14 / \mathrm{M}$ & 26 & $\operatorname{IgH}$ & $10^{-4}$ \\
\hline 5 & $5 / \mathrm{F}$ & 9 & $\operatorname{IgH}$ & $10^{-3}$ \\
\hline 6 & $13 / \mathrm{F}$ & 31 & $\operatorname{IgH}$ & UK \\
\hline 7 & $11 / \mathrm{F}$ & 64 & $\mathrm{IgH}$ & $10^{-3}$ \\
\hline 8 & $4 / \mathrm{M}$ & 35 & $\operatorname{IgH}$ & UK \\
\hline 9 & $8 / \mathrm{F}$ & 42 & $\mathrm{IgH}$ & $10^{-4}$ \\
\hline 10 & $8 / \mathrm{F}$ & 70 & TcR & $10^{-3}$ \\
\hline 11 & $7 / \mathrm{F}$ & 85 & $\operatorname{IgH}$ & $10^{-5}$ \\
\hline 12 & $7 / \mathrm{M}$ & 86 & $\mathrm{TcR}$ & $10^{-4}$ \\
\hline 13 & $5 / \mathrm{F}$ & 28 & $\mathrm{TcR}$ & UK \\
\hline 14 & $15 / \mathrm{M}$ & 24 & $\mathrm{IgH}+\mathrm{TcR}$ & $10^{-5}$ \\
\hline 15 & $12 / \mathrm{F}$ & 24 & $\operatorname{IgH}$ & $10^{-4}$ \\
\hline 16 & $5 / \mathrm{M}$ & 15 & - & - \\
\hline 17 & $4 / \mathrm{M}$ & 27 & $\mathrm{TcR}$ & $10^{-5}$ \\
\hline 18 & $9 / \mathrm{M}$ & 24 & TcR & UK \\
\hline 19 & $5 / \mathrm{M}$ & 42 & $\operatorname{IgH}$ & $10^{-4}$ \\
\hline 20 & $5 / \mathrm{M}$ & 30 & TcR & $10^{-6}$ \\
\hline 21 & $1 / \mathrm{M}$ & 33 & - & - \\
\hline 22 & $3 / \mathrm{M}$ & 48 & $\mathrm{IgH}$ & UK \\
\hline 23 & $3 / \mathrm{M}$ & 25 & $\mathrm{IgH}$ & $10^{-4}$ \\
\hline 24 & $2 / \mathrm{M}$ & 34 & $\operatorname{IgH}$ & $10^{-3}$ \\
\hline 25 & $4 / F$ & 70 & - & - \\
\hline 26 & $5 / \mathrm{M}$ & 39 & - & - \\
\hline 27 & $2 / \mathrm{F}$ & 27 & $\operatorname{IgH}$ & $10^{-4}$ \\
\hline 28 & $6 / \mathrm{M}$ & 39 & TcR & $10^{-5}$ \\
\hline
\end{tabular}

*When both IgH and TcR rearrangements were present, the rearrangement resulting in a probe that detected leukaemic cells with the highest sensitivity as determined with the dilution series is shown; age = age at diagnosis; M: male; F: female; -: no antigen receptor rearrangement could be amplified by PCR; UK: unknown, because no dilution series was available for these patients (DNA was extracted from glass slides instead of from frozen cells).

cells, the samples obtained after purging (except for patients 3,4 and 15) were also subjected to two incubations of $1 \mathrm{~h}$ each at $37^{\circ} \mathrm{C}$ in RPMI medium supplemented with $100 \mu \mathrm{g} / \mathrm{ml}$ DNAse (Sigma, type IV from bovine pancreas). Previous experiments had shown that this procedure resulted in optimal elimination of DNA from lysed cells that could give rise to false positive results in the PCR analysis (unpublished observations).

Polymerase chain reaction. DNA was isolated from the cell suspensions by proteinase $\mathrm{K}$ digestion and phenol/chloroform extraction as described previously (Steenbergen et al, 1995b). PCR reactions contained $1 \mu \mathrm{g}$ genomic DNA (equivalent of approximately $10^{5}$ cells). Immunoglobulin heavy chain $\mathrm{V}_{\mathrm{H}} \mathrm{DJ} \mathrm{H}_{\mathrm{H}}$ junctional regions (CDRIII) and T-cell receptor (TCR) V $\delta 2 \mathrm{D} \delta 3$ junctional regions were amplified by PCR as described (Steenbergen et al, 1995b). Briefly, CDRIII regions were amplified with a consensus Framework region 3 primer (FR3) and a consensus joining primer (JH21). For the amplification of TCR $V \delta 2 \mathrm{D} \delta 3$ rearrangements from relapse and diagnosis samples, a semi-nested PCR approach was used. For analysis of serial dilutions and remission BM a single round of PCR was performed. To check DNA quality, all DNA samples were subjected to a PCR with primer pair PCO3-PCO4 which amplifies a 110 base pair product from the first exon of the human $\beta$-globin gene (Saiki et al, 1985). PCR products were separated according to size by electrophoresis on an acrylamide gel, re-amplified with the original primers and directly sequenced. ${ }^{32}$ P-labelled patient-specific oligonucleotides were generated and hybridized to the PCR products by liquid hybridization (Steenbergen et al, 1995b). For semi-quantification of residual malignant cells, DNA from 10-fold serial dilutions of patient cells (always more than $90 \%$ leukaemic blasts as starting material) in PB MNC were subjected to the same protocol. Steenbergen et al (1995b) previously showed that this technique enables the monitoring of minimal residual disease with acceptable sensitivities (at least one malignant cell in $10^{4}$ normal cells could be detected for $85 \%$ of evaluable patients). 


\section{Susan F. Vervoordeldonk et al}

Statistical analysis. For statistical analysis of differences in purging efficacy using cell lines, Student's $t$ tests and for comparison of patient groups Fisher's Exact Tests were done.

\section{RESULTS}

Purging efficacy determined in model experiments

The efficacy of the purging procedure was tested by simulating leukaemia-contaminated remission BM, using a mixture of $5 \%$ cell line cells and normal BM cells. Fig 1 shows that complement-mediated cell lysis with CD9 and CD10 MoAbs resulted in a $0 \cdot 4-3 \cdot 0 \mathrm{log}$ depletion of clonogenic tumour cells, depending on the cell line used for the experiment. Addition of immunorosette depletion to the purging procedure resulted in a significantly increased elimination of leukaemic cells as is shown for cell lines Ros $(P<0.005)$ and Nalm-6 $(P<0.025)$. These results confirm and extend our earlier findings (Slaper-Cortenbach et al, 1990).

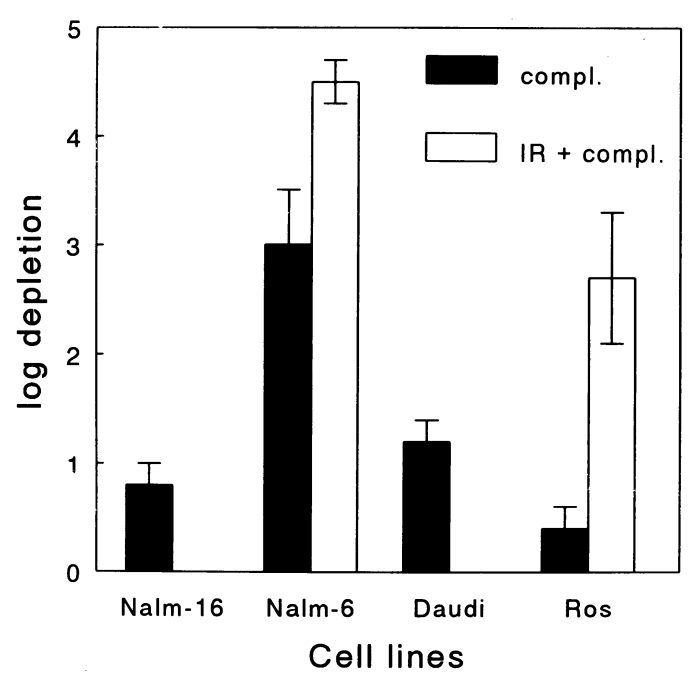

Fig 1. Remission BM was simulated by mixing $5 \%$ cell line cells with irradiated normal BM cells. For four cell lines the effect of complement-mediated cell lysis was tested (solid bars) and for Nalm- 6 and Ros the effect of the two-step purging procedure was also determined (open bars) in clonogenic assays. Results are expressed as log depletion of clonogenic cells. Shown are average values of three or more experiments \pm standard error of the mean (SEM). compl.: complement-mediated cell lysis; IR: immunorosette depletion.

\section{Evaluation of treatment}

Of the 28 patients included in this study, 10 patients (36\%) remain in continuous complete remission after ABMT with a median follow-up of 23 months (range 13-76 months). The length of first complete remission in these 10 patients was $>2$ years. Patient 6 died due to transplant-related toxicity. Patient 25 relapsed before ABMT could be performed. The remaining 16 patients relapsed within the first 13 months after ABMT, except for patient 7 who relapsed after 53 months. The duration of first complete remission was 2 years or less in $5 / 16$ patients who relapsed $(P=0 \cdot 1213)$.
Tumour cell contamination at time of bone marrow harvest and correlation with clinical outcome

In 24/28 (86\%) patients a PCR product was obtained by amplification of IgH and/or TCR junctional regions (Table I). Patient-specific probes were generated and hybridized to PCR products from serial dilutions of patient cells in PB MNC. When both IgH and TcR rearrangements were present, the rearrangement resulting in a probe that detected leukaemic cells with the highest sensitivity as determined with the dilution series is shown in Table I. Of probes derived from five patients the sensitivity could not be determined. For these patients, DNA was isolated from cells obtained from glass slides, so no dilution series could be made. A sensitivity equal to or higher than approximately one cell in $10^{4}\left(10^{-4}\right.$, estimated from the results from the semi-quantitative PCR) was obtained with probes from $15 / 19$ patients $(80 \%)$.

For 13 patients BM before purging was available for analysis. Leukaemic cells were detected by PCR at the time of BM harvest in $8 / 13$ patients $(62 \%$, Tables II and III). All these patients experienced a relapse as compared to $0 / 5$ patients in whom no leukaemic cells were detected by PCR $(P=0.0008)$. PB was obtained the day before BM harvest from 10 patients. Tumour cells were detectable in the MNC isolated from $\mathrm{PB}$ of only two patients with heavily contaminated BM (1-10\% leukaemic cells as estimated by the PCR results).

Results of in vitro treatment of bone marrow and correlation with clinical outcome

After completion of the purging procedure, residual leukaemic cells were detected in the BM of 9/24 patients (Tables II and III). All these nine patients experienced a BM

Table II. Detection of residual malignant cells in BM samples of patients whose BM was purged by complement lysis alone.

\begin{tabular}{rlll}
\hline & & & Outcome after \\
Patient & Pre-purge & After purge & ABMT \\
\hline 1 & ND & - & $\mathrm{R}(13)$ \\
2 & +1 & + & $\mathrm{R}(4)$ \\
3 & +3 & + & $\mathrm{R}(8)$ \\
4 & ND & + & $\mathrm{R}(12)$ \\
5 & ND & + & $\mathrm{R}(1)$ \\
6 & ND & - & Tox. \\
7 & ND & - & $\mathrm{R}(53) / \mathrm{CR}(4)$ \\
8 & ND & - & $\mathrm{R}(13)^{\mathrm{c}}$ \\
9 & ND & - & $\mathrm{CR} 2(76)$ \\
10 & ND & - & $\mathrm{CR} 2(68)$ \\
& & & \\
\hline
\end{tabular}

ND: not done; PCR data are expressed as + or - , indicating PCR positivity or negativity. Numbers indicate the level of positivity as estimated in a semi-quantitative PCR $(+2$ means 1:100 cells positive when compared with a dilution series, +3 means 1:1000 cells positive, etc.); Tox.: this patient died from transplant-related toxicity; ${ }^{c}$ : the relapse of this patient was a CNS relapse; figures in parentheses indicate the time from ABMT to relapse (months) or the duration of follow-up for patients remaining in $\mathrm{CR}$. 
Table III. Detection of residual malignant cells in PBL and BM samples of patients whose BM was purged by the two-step procedure.

\begin{tabular}{llllll}
\hline & & & & & \\
Patient & PB-MNC & BM pre-purge & After IR & After purge & $\begin{array}{l}\text { Outcome after } \\
\text { ABMT }\end{array}$ \\
\hline 11 & ND & ND & ND & + & R (3) \\
12 & ND & ND & ND & - & R (8) \\
13 & ND & ND & ND & - & CR2 (61) \\
14 & - & +3 & ND & + & R (8) \\
15 & ND & +4 & + & + & R (9) \\
17 & - & - & - & - & CR2 (33) \\
18 & - & + & ND & - & R (6) \\
19 & - & - & - & - & CR2 (25) \\
20 & +1 & +1 & + & - & R (8) \\
22 & - & + & + & + & CR2 (19) \\
23 & - & - & - & - & CR2 (19) \\
24 & - & - & - & - & R (3) \\
27 & +2 & +2 & - & - & CR2 (13) \\
28 & - & - & + & & \\
\hline
\end{tabular}

ND: not done; PCR data are expressed as + or -, indicating PCR positivity or negativity. Numbers indicate the level of positivity as estimated in a semi-quantitative PCR ( +2 means 1:100 cells positive when compared with a dilution series, +3 means 1:1000 cells positive, etc.); IR: immunorosette depletion; figures in parentheses indicate the time from ABMT to relapse (months) or the duration of follow-up for patients remaining in CR.

relapse within the first year after ABMT. 15 patients received a PCR-negative graft. One patient died of transplant-related toxicity and was excluded from this analysis. A relapse (five $\mathrm{BM}$ and one CNS) occurred in only 6/14 patients whose grafts were negative by PCR after purging $(P=0 \cdot 0072)$. In two of these six patients, leukaemic cells were detected before purging, whereas in the other four patients no material was available for analysis of pre-purge BM.
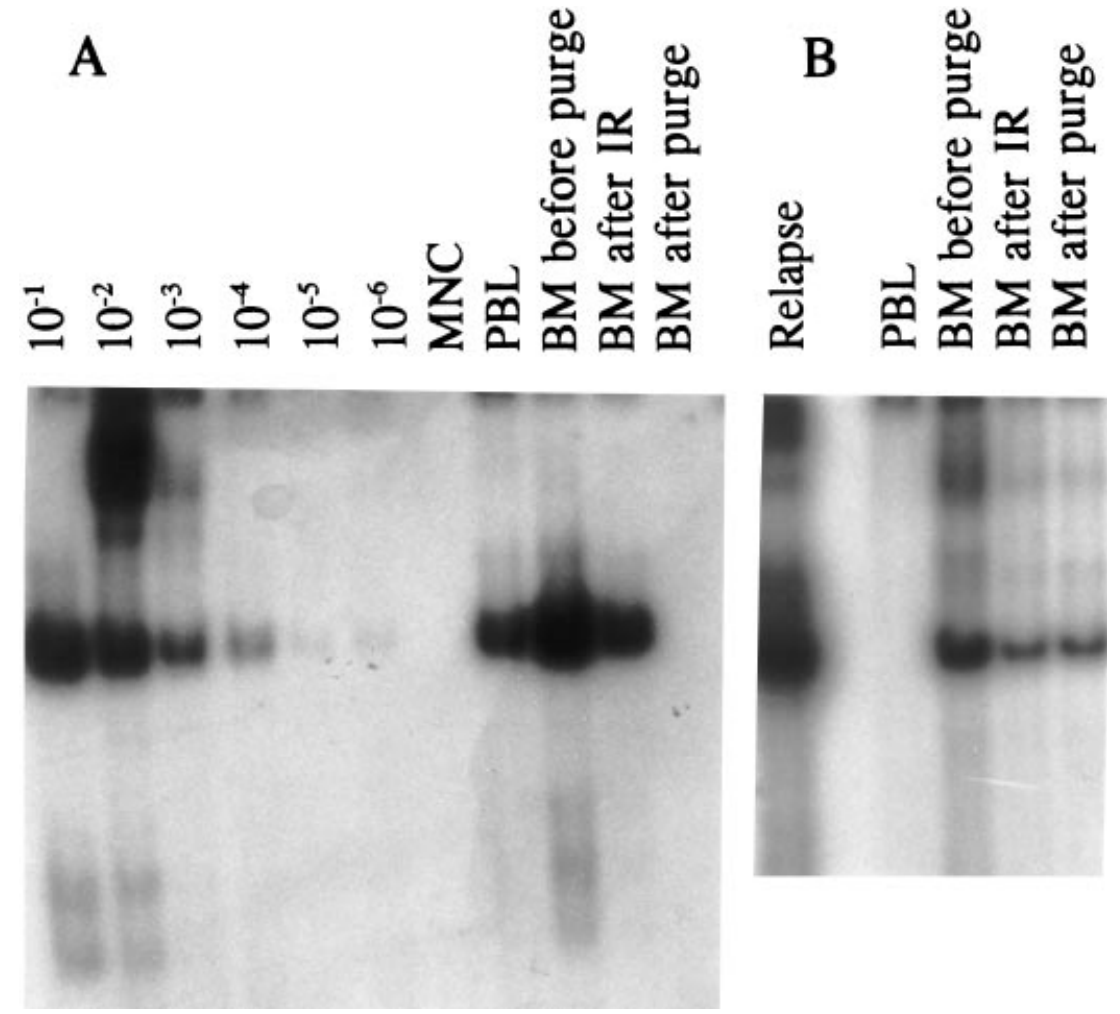

Fig 2. Detection of residual leukaemic cells by PCR is shown for patients 20 (A) and 22 (B). In A, a dilution series is shown of material obtained at relapse diluted in normal mononuclear cells (MNC). PBL: peripheral blood lymphocytes obtained the day before bone marrow (BM) harvest; IR: immunorosette depletion. 


\section{Susan F. Vervoordeldonk et al}

The BM of four of the 10 patients whose BM was purged by complement alone was positive after purging. BM before purging could only be evaluated in two patients. The BM of both these patients remained PCR-positive after purging.

Samples after immunorosette depletion were collected from nine patients. The BM of five of these patients was negative by PCR before purging, whereas in four patients residual leukaemic cells could be detected. In the BM of all these four patients leukaemic cells were still detectable after immunorosette depletion and before complement-mediated cell lysis. Leukaemic cells were still detected in 5/14 patients after completion of the two-step purging procedure. PCR results were negative after purging in only $2 / 6$ patients whose BM contained residual tumour cells before purging. However, these patients relapsed 6 and 8 months after transplantation. So, in summary, PCR positivity in the graft predicted relapse, whereas PCR negativity did not exclude relapse.

In patient 20, residual tumour cells were still detected after immunorosette depletion, but PCR was negative after the second purging step (Fig 2A). Fig 2B shows the results from patient 22 , whose $\mathrm{BM}$ still contained residual leukaemic cells after both purging steps. This patient relapsed 5 months after ABMT. Immunophenotyping data were available for 21 patients. No correlation was observed between the ability to purge contaminated BM grafts to PCR negativity and the expression of CD9, CD10, CD19 and/or CD22.

\section{DISCUSSION}

The high incidence of relapse after autologous bone marrow transplantation using a purged graft in children with precursor B ALL can be due to several factors. The pretransplant conditioning regime may not have completely eliminated residual leukaemia in the patient, as a result of drug resistance or resistance to radiation therapy. The absence of a graft-versus-leukaemia effect (which may occur in allogeneic BM transplantation) may also influence the final outcome in these patients. Finally, inefficient purging and subsequent reinfusion of malignant cells into the patient may contribute to relapse.

The results from our study indicate that both the antileukaemic treatment and the purging procedure need to be optimized. Leukaemic burden in the pre-purge BM grafts correlated strongly with relapse. This confirms the results from the Minneapolis group (Uckun et al, 1993 1992). In their studies, multiparameter flow cytometry and cell sorting were combined with a colony assay for leukaemic progenitor cells in a quantitative method for the detection of MRD. The pre-purge leukaemic burden correlated with the clinical outcome. Similar results were obtained by Seriu et al (1995). They reported the application of peripheral stem cell transplantation in five patients with precursor B ALL. Leukaemic cells were detected by PCR in peripheral blood stem cell autografts in $4 / 5$ patients. Three of these four patients relapsed within 6 months after transplantation.

A strong suggestion that reinfusion of malignant cells that are present in autologous BM grafts contributes to relapse was provided by Gribben et al (1991). In a group of adult patients with B-cell lymphoma, all BM grafts contained residual malignant cells at harvest as detected by polymerase chain reaction (PCR). After purging with monoclonal antibodies (MoAb) and complement, malignant cells could no longer be detected in BM grafts of $50 \%$ of the patients. Disease-free survival in this group was significantly more common than in those patients whose marrow still contained detectable residual lymphoma cells. For patients with acute myeloid leukaemia, neuroblastoma, and chronic myelogenous leukaemia, gene marking of the autologous marrow has shown that malignant cells from the graft were present at relapse (Brenner et al, 1993; Rill et al, 1994; Deisseroth et al, 1994). These studies suggest that elimination of malignant cells from the graft might increase disease-free survival. In our study, all patients whose marrow contained residual malignant cells after purging, experienced a relapse, as compared to 6/14 whose BM was PCR-negative after purging $(P=0.0072)$. However, this does not prove that leukaemic cells in the graft contributed to relapse. As suggested by others (Gribben \& Nadler, 1995; Lazarus et al, 1993; Murgo et al, 1992), the inability to purge tumour cells from the graft might also reflect more resistant disease. However, the relation between drug resistance and, for example, resistance to complement mediated lysis, is not clear.

In cell line experiments, a 2.5-4.5 log depletion of malignant cells was achieved with our current purging protocol, as compared to $0.4-3.0$ log depletion when complement lysis was applied without immunorosette depletion. Although the purging efficacy in autologous BM grafts could not be exactly determined by the semi-quantitative PCR assay, the estimated tumour contamination in BM grafts before and after purging suggests a considerable variety in purging efficacy among patients. For example, patient 20 had a large tumour burden (approximately 10\%) before purging, which was reduced to PCR negativity after purging (with the patient specific probe, approximately one leukaemic cell could be detected among $10^{6}$ normal cells). In contrast, tumour contamination of the $\mathrm{BM}$ at harvest of patient 15 was at the level of the detection limit (with the patient-specific probe, approximately one leukaemic cell could be detected among $10^{4}$ normal cells) and remained PCR positive after the two-step purging procedure. A large variation in purging efficacy between patients has also been observed by others, either by immunofluorescence techniques (Garcia et al, 1994), PCR (Gribben et al, 1991) or colony assays (Uckun et al, 1992).

Heterogenous distribution of leukaemia in the BM (Hann et al, 1977; Martens et al, 1987) can be a cause of sample error and false-negative results by PCR or of an inaccurate estimation of leukaemic burden at the time of BM harvest. False-negative results can also be caused by ongoing antigen receptor gene rearrangements. As a consequence, patientspecific probes derived from the rearrangement at diagnosis might not hybridize with the amplified rearrangement from material obtained at relapse. However, from most of the patients analysed in this study, probes were derived from material obtained at first BM relapse and we have shown 
previously that clonal changes did not occur from first relapse onward (Steenbergen et al, 1995a). False-positive results can be due to amplification of DNA from lysed cells. In order to prevent this, we developed a procedure of incubating thawed cells with high concentrations of DNAse which reduces the risk of co-purification of DNA from lysed cells.

Garcia et al (1994) reported an improved, although not statistically significant, disease-free survival for ALL patients in whom at least a $1.5 \mathrm{log}$ depletion of leukaemic cells was achieved by complement lysis as compared to cases in which purging was less efficient or in patients who received unpurged autologous BM. Results from their study are obscured by the fact that the purged group contained more patients transplanted in first complete remission (10/32) than patients in the unpurged group (2/14). Gilmore et al (1991) concluded that effective in vitro purging by complement-mediated cell lysis of remission BM in patients with both precursor B and T ALL appeared not to improve the outcome in high-risk patients transplanted in first remission. However, purge efficacy in this study was estimated by fluorescence techniques and Southern blotting which does not allow detection of $<1 \%$ of tumour cells.

In conclusion, in this study remission BM of $62 \%$ of patients with precursor B ALL was contaminated with leukaemic cells despite 6 months of intensive chemotherapy. Regardless of whether the purging procedure was succesful (defined by achievement of PCR negativity) or not, all these patients experienced a relapse after transplantation, indicating that the antileukaemic treatment was insufficient. If the results from this study are confirmed in a large prospective study, PCR analysis of the graft at BM harvest will be able to predict the clinical outcome after ABMT. Accordingly, the decision of whether ABMT should be performed can then be based on the outcome of this analysis. The number of patients whose BM was evaluated both before and after purging was too small to draw definite conclusions on the benefit of purging. The finding that only $25 \%$ of the PCR-positive grafts could be purged to PCR-negativity suggests that optimization of our purging procedure is also necessary.

\section{ACKNOWLEDGMENTS}

We acknowledge the expert technical assistance of O. J. M. Verhagen in some of the PCR experiments. Purging and processing of the BM grafts was performed by M. J. G. J. Wijngaarden-du Bois, A. de Vries-van Rossen, A. Vos and A. Zadurian. The Dutch Childhood Leukaemia Study Group (DCLSG) kindly provided several leukaemic cell samples. Board members of the DCLSG are H. van den Berg, J. P. M. Bökkerink, M. V. A. Bruin, K. Hählen, W. A. Kamps, F. A. E. Nabben, A. Postma, J. A. Rammeloo, I. M. Risseeuw-Appel, A. Y. N. Schouten-van Meeteren, E. Th. van 't Veer-Korthof, A. J. P. Veerman, M. van Weel-Sipman and R. S. Weening.

This study was financially supported in part by the Foundation for Paediatric Cancer Research (grant number 90-03) and the Foundation Floortje Peneder.

\section{REFERENCES}

Bast, C., De Fabritiis, P., Lipton, J., Gelber, R., Maver, C., Nadler, L., Sallan, S. \& Ritz, J. (1985) Elimination of malignant clonogenic cells from human bone marrow using multiple monoclonal antibodies and complement. Cancer Research, 45, 499-503.

Behrendt, H., van Leeuwen, E.F., Schuwirth, C., Verkes, R.J., Hermans, J., Van der Does-Van den Berg, A. \& van Wering, E.R. (1990) Bone marrow relapse occurring as first relapse in children with acute lymphoblastic leukaemia. Medical and Pediatric Oncology, 18, 190-196.

Billett, A.L., Kornmehl, E., Tarbell, N.J., Weinstein, H.J., Gelber, R.D., Ritz, J. \& Sallan, S.E. (1993) Autologous bone marrow transplantation after a long first remission for children with recurrent acute lymphoblastic leukemia. Blood, 81, 1651-1657.

Brenner, M.K., Rill, D.R., Moen, R.C., Krance, R.A., Mirro, J.J., Anderson, W.F. \& Ihle, J.N. (1993) Gene-marking to trace origin of relapse after autologous bone-marrow transplantation. Lancet, 341, 85-86.

Campana, D. \& Pui, C. (1995) Detection of minimal residual disease in acute leukemia: methodological advances and clinical significance. Blood, 85, 1416-1434.

Culbert, S.J., Shuster, J.J., Land, V.J., Wharam, M.D., Thomas, P.R., Nitschke, R., Pinkel, D. \& Vietti, T.J. (1991) Remission induction and continuation therapy in children with their first relapse of acute lymphoid leukaemia: a Pediatric Oncology Group study. Cancer, 67, 37-42.

Deisseroth, A.B., Zu, Z., Claxton, D., Hanania, E.G., Fu, S., Ellerson, D., Goldberg, L., Thomas, M., Janicek, K., Anderson, W.F., Hester, J., Korbling, M., Durett, A., Moen, R., Berenson, R., Heimfeld, S., Hamer, J., Calvert, L., Tibbits, P., Talpaz, M., Kantarjian, H., Champlin, R., Reading, C. (1994) Genetic marking shows that $\mathrm{Ph}+$ cells present in autologous transplants of chronic myelogenous leukemia (CML) contribute to relapse after autologous bone marrow in CML. Blood, 83, 3068-3076.

Garcia, J., Punti, C., Picon, M., Tigues, D., Amill, B., Canals, C., Ayats, R., Ramon, I., Gilabert, R., Sierra, J., Badell, I., Brunet, S., Ortega, J., Valls, A. \& Granena, A. (1994) Bone marrow purging in acute lymphoblastic leukemia: biological and clinical features. Journal of Hematotherapy, 3, 203-211.

Gilmore, M.J., Hamon, M.D., Prentice, H.G., Katz, F., Slaper Cortenbach, I.C., Hunter, A.E., Gandhi, L., Brenner, M.K., Hoffbrand, A.V., Mehta, A.B., Secker-Walker, L.M., Skeggs, D. \& Collis, C.H. (1991) Failure of purged autologous bone marrow transplantation in high risk acute lymphoblastic leukemia in first complete remission. Bone Marrow Transplantation, 8, 19-26.

Gribben, J.G., Freedman, A.S., Neuberg, D., Roy, D.C., Blake, K.W., Woo, S.D., Grossbard, M.L., Rabinowe, S.N., Coral, F., Freeman, G.J., Ritz, J. \& Nadler, L.M. (1991) Immunologic purging of marrow assessed by PCR before autologous bone marrow transplantation for B-cell lymphoma. New England Journal of Medicine, 325, 1525-1533.

Gribben, J.G. \& Nadler, L.M. (1995) Purging of bone marrow. Biologic Therapy of Cancer (ed. by V. T. DeVita, S. Hellman and S. A. Rosenberg), p. 596. J. B. Lippincott Company, Philadelphia.

Hann, I.M., Morris Jones, P.H. \& Evans, D.I.K. (1977) Discrepancy of bone-marrow aspirations in acute lymphoblastic leukaemia in relapse. Lancet, i, 1215-1216.

Henze, G., Fengler, R., Hartmann, R., Kornhuber, B., Janka Schaub, G., Niethammer, D. \& Riehm, H. (1991) Six-year experience with a comprehensive approach to the treatment of recurrent childhood acute lymphoblastic leukemia (ALL-REZ BFM 85): a relapse study of the BFM group. Blood, 78, 1166-1172.

Kersey, J.H., Weisdorf, D., Nesbit, M.E., LeBien, T.W., Woods, W.G., McGlave, P.B., Kim, T., Vallera, D.A., Goldman, A.I., Bostrom, B., 


\section{Susan F. Vervoordeldonk et al}

Hurd, D. \& Ramsay, N.K. (1987) Comparison of autologous and allogeneic bone marrow transplantation for treatment of high-risk refractory acute lymphoblastic leukemia. New England Journal of Medicine, 317, 461-467.

Lansdorp, P.M., Aalberse, R.C., Bos, R., Schutter, W.G. \& van Bruggen, E.F.J. (1986) Cyclic tetramolecular complexes of monoclonal antibodies: a new type of cross-linking reagent. European Journal of Immunology, 16, 679.

Lazarus, H.M., Rowe, J.M. \& Goldstone, A.H. (1993) Does in vitro bone marrow purging improve the outcome after autologous bone marrow transplantation? Journal of Hematotherapy, 2, 457-466.

Martens, A.C., Schultz, F.W. \& Hagenbeek, A. (1987) Nonhomogeneous distribution of leukemia in the bone marrow during minimal residual disease. Blood, 70, 1073-1078.

Moussalem, M., Esperou Bourdeau, H., Devergie, A., Baruchel, A., Ribaud, P., Socie, G., Parquet, N., Traineau, R., Hirsch, I., Schaison, G. \& Gluckman, E. (1995) Allogeneic bone marrow transplantation for childhood acute lymphoblastic leukemia in second remission: factors predictive of survival, relapse and graftversus-host disease. Bone Marrow Transplantation, 15, 943-947.

Murgo, A.J., Weinberger, B.B. \& Johnson, J.R. (1992) Immunologic purging of marrow assessed by polymerase chain reaction. New England Journal of Medicine, 326, 1163.

Negrin, R.S. (1992) Use of the polymerase chain reaction for the detection of tumor cell involvement of bone marrow and peripheral blood: implications for purging. Journal of Hematotherapy, 1, 361-368.

Pui, C. (1995) Childhood leukemias. New England Journal of Medicine, 332, 1618-1630.

Reiter, A., Schrappe, M., Ludwig, W., Hiddemann, W., Sauter, S. Henze, G., Zimmermann, M., Lampert, F., Havers, W., Niethammer, D., Odenwald, E., Ritter, J., Mann, G., Welte, K., Gadner, H. \& Riehm, H. (1995) Chemotherapy in 998 unselected childhood acute lyphoblastic leukemia patients: results and conclusions of the multicenter trial ALL-BFM 86. Blood, 84, 3122-3133.

Rill, D.R., Santana, V.M., Roberts, W.M., Nilson, T., Bowman, L.C., Krance, R.A., Heslop, H.E., Moen, R.C., Ihle, J.N. \& Brenner, M.K. (1994) Direct demonstration that autologous bone marrow transplantation for solid tumours can return a multiplicity of tumorigenic cells. Blood, 84, 380-383.

Saiki, RK., Scharf, S., Faloona, F., Mullis, KB., Horn, GT., Erlich, H.A. \& Arnheim, N. (1985) Enzymatic amplification of $\beta$-globin genomic sequences and restriction site analysis for diagnosis of sickle cell anemia. Science, 230, 1350-1354.

Sallan, S.E., Niemeyer, C.M., Billett, A.L., Lipton, J.M., Tarbell, N.J., Gelber, R.D., Murray, C., Pittinger, T.P., Wolfe, L.C., Bast, R.C.J. \& Ritz, J. (1989) Autologous bone marrow transplantation for acute lymphoblastic leukaemia. Journal of Clinical Oncology, 7, 1594-1601.

Seriu, T., Yokota, S., Nakao, M., Misawa, S., Takaue, Y., Koizumi, S., Kawai, S. \& Fujimoto, T. (1995) Prospective monitoring of minimal residual disease during the course of chemotherapy in patients with acute lymphoblastic leukemia, and detection of contaminating tumor cells in peripheral blood stem cells for autotransplantation. Leukemia, 9, 615-623.

Simonsson, B., Burnett, A.K., Prentice, H.G., Hann, I.H., Brenner, M.K., Gibson, B., Grob, J.P., Lonnerholm, G., Morrison, A., Smedmyr, B., Todd, A., Oberg, G., Gilmore, M., Campana, D. \& Totterman, Th. (1989) Autologous bone marrow transplantation with monoclonal antibody purged marrow for high risk acute lymphoblastic leukemia. Leukemia, 3, 631-636.

Slaper-Cortenbach, I.C.M., Admiraal, L.G., van Leeuwen, E.F., Kerr, J.M., von dem Borne, A.E.G.Kr. \& Tetteroo, P.A.T. (1990) Effective purging of bone marrow by a combination of immunorosette depletion and complement lysis. Experimental Hematology, 18, 49-54.

Steenbergen, E.J., Verhagen, O.J.H.M., van Leeuwen, E.E., van den Berg, H., Behrendt, H., Slater, R.M., von dem Borne, A.E.G.Kr. \& van der Schoot, C.E. (1995a) Prolonged persistence of PCRdetectable minimal residual disease after diagnosis or first relapse predicts poor outcome in childhood B-precursor acute lymphoblastic leukemia. Leukemia, 9, 1726-1734.

Steenbergen, E.J., Verhagen, O.J.H.M., Van Leeuwen, E.F., van den Berg, H., Behrendt, H., Von dem Borne, A.E.G.Kr. \& Van der Schoot, C.E. (1995b) IgH/TCRd PCR oligonucleotide liquid hybridization, a fast and sensitive assay for monitoring minimal residual disease in childhood B-precursor ALL. Leukemia, 9, 216-222.

Uckun, F.M., Kersey, J.H., Haake, R., Weisdorf, D., Nesbit, M.E. \& Ramsay, N.K. (1993) Pretransplantation burden of leukemic progenitor cells as a predictor of relapse after bone marrow transplantation for acute lymphoblastic leukemia. New England Journal of Medicine, 329, 1296-1301.

Uckun, F.M., Kersey, J.H., Haake, R., Weisdorf, D. \& Ramsay, N.K. (1992) Autologous bone marrow transplantation in high-risk remission B-lineage acute lymphoblastic leukemia using a cocktail of three monoclonal antibodies (BA-1/CD24, BA-2/ CD9, and BA-3/CD10) plus complement and 4-hydroperoxycyclophosphamide for ex vivo bone marrow purging. Blood, 79, 1094-1104.

van den Berg, H., Vet, R., den Ouden, E. \& Behrendt, H. (1995) Significance of lymphoblasts in cerebrospinal fluid in newly diagnosed pediatric acute lymphoblastic malignancies with bone marrow involvement: possible benefit of dexamethasone. Medical and Pediatric Oncology, 25, 22-28.

Van der Does-Van den Berg, A., van Wering, E.R., Suciu, S., Solbu, G., van't Veer, M.B., Rammeloo, J.A., De Koning, J. \& van Zanen, G.E. (1989) Effectiveness of rubidomycin in induction therapy with vincristine, prednisone, and L-asparaginase for standard risk childhood acute lymphocytic leukemia: results of a Dutch Phase III study (ALL V). American Journal of Pediatric Hematology/ Oncology, 11, 125-133.

Veerman, A.J.P., Hahlen, K., Kamps, W.A., van Leeuwen, E.F., de Vaan, G.A.M., van Wering, E.R., Van der Does-Van den Berg, A., Solbu, G. \& Suciu, S. (1990) Dutch Childhood Leukemia Study Group: early results of Study ALLVI(1984-1988). Haematology and Blood Transfusion, Vol. 33 (eds Buchner et al), p. 473. Springer, Berlin. 